\title{
Mammalian Neuro Endocrinological Changes and Oxidative Stress during Chronic Lead Intoxication
}

\section{G. Edrees*, Amer M, El-shamy K and Atta N}

Department of Zoology, Faculty of Science, Mansoura University, Egypt National Research Center, Egypt

\begin{abstract}
The dangerous effect of lead was evaluated in male mice exposed to lead acetate at dose 2000 and 4000 ppm in drinking water, as well as subjects working in fields with high lead levels. Lead exposure exhibited marked decrease in body weight, as well as in hematological parameters such as hemoglobin content, hematocrit percent, erythrocytes and leucocytes count. In addition, there was a disruptive effect on neurological and endocrinological systems reflected by alterations in T3, T4, testosterone and cortisol hormones. In contrast, there was an elevation in serotonin level, along with a reduction in the concentrations of plasma $\mathrm{Zn}$ and Fe in lead exposed mice and human individuals. The study showed increases in the lipid peroxidation product (MDA), accompanied with decreases in GSH and SOD in lead exposed subjects and animals. The study thus indicated that exposure to lead pollution should be avoided as it affect neuro-endocrinological systems, increases oxidative stress and decreases fertility.
\end{abstract}

Keywords: Lead acetate; Oxidative stress; Fertility; Testosterone

\section{Introduction}

The toxic effects of lead demand particular attention because of its characteristically cumulative feature associated with slow turnover and a long biological half-life [1]. It has been estimated that more than half of lead found within the atmosphere arose from the burning of tetraethyl lead, a compound added to gasoline to reduce engine knocking [2].

Lead exposure can arise from contact with lead based paints at home, crop enhancers (fertilizers), cosmetics, and automobiles (gasoline and disposable batteries), especially in developing countries [3]. Lead adversely affects many organs and systems in humans exposed workers, where the hematological system is one of the major targets after oxidative stress [4]. Also, lead exposure damages different vitally important systems, especially the central nervous system (CNS), after its penetration into the body with food, water and air containing the exhaust of engines that run on gasoline [5]. Lead is recognized as a dangerous neurotoxin, even at low levels of exposure [6,7] showed that oxidative stress may be an important factor in the neurotoxic effects of lead. Villeda-Hernandez et al. [8] showed that, oxidative stress can cause damage to biomolecules by free radical attachment to polyunsaturated fatty acid (PUFA) side chains in cells and this leads to lipid peroxidation which produces malondialdehyde (MDA), being toxic in nature. They also reported that, lead induced monoamine oxidase (MAO) activity and consequently affected dopamine metabolism in most of brain regions.

Lead exposure impairs several neurotransmitters systems, including acetyle-choline, dopamine, norepinephrine, and gammaaminobutyric acid (GABA) dependent systems [9].

As special attention has been paid to health hazards of environmental pollution, the aim of the present work is to evaluate the toxic effects of lead exposure at hormonal and neurotransmitters level in mice and human.

\section{Materials and Methods}

\section{Chemicals}

Lead acetate was purchased from Sigma Company for chemicals, Egypt, and the other chemicals used were with high grade of purity.

\section{Experimental design}

Animals: Healthy Swiss male albino mice weighing 22-24 g were used. They were housed in stainless steel cages in experimental animal care center, Mansoura University. Animals were kept under good ventilation, temperature $22-24^{\circ} \mathrm{C}$, and provided balanced chow diet, and water ad libitum. Animal husbandry and experimentation were consistent with the public health guide for the care and use of laboratory animals at National Research Council, 1996.

Mice were randomly divided into 3 groups $(n=10)$ as follows: control group, lead acetate orally treated groups at doses (2000 ppm) and (4000 ppm), for 10 weeks. Body weight changes were recorded every week along experimentation period.

At the end of experimentation period (10 weeks) animals were sacrificed by cervical dislocation after overnight fasting, and blood samples were collected in clean non-heparinized tubes. Sera were separated by centrifugation at $3000 \mathrm{rpm}$ for $15 \mathrm{~min}$ and stored at $-20^{\circ} \mathrm{C}$ for biochemical analysis. Packed blood cells were obtained for lead determination. Other blood samples were collected in heparinized tubes, a part was used for blood picture determination. The other part was centrifuged at $3000 \mathrm{rpm}$ for $15 \mathrm{~min}$ to obtain plasma for $\mathrm{Zn}$ and $\mathrm{Fe}$ as well as hormonal determinations. Brains of mice were separated, and weighed immediately, and then parts of them was frozen at $-80^{\circ} \mathrm{C}$ for neurotransmitters estimation, other parts of brains was homogenized in ice cold saline solution and frozen at $-80^{\circ} \mathrm{C}$ till used for biochemical analysis (GSH, MDA, SOD).

Human subjects: Male volunteers aged 20-35 years old were

*Corresponding author: Edrees G, Department of Zoology, Faculty of Science, Mansoura University, Egypt National Research Center, Egypt, E-mail: gamaledrees600@yahoo.com

Received January 02, 2013; Accepted January 27, 2013; Published February 01,2013

Citation: Edrees G, Amer M, El-shamy K, Atta N (2013) Mammalian Neuro Endocrinological Changes and Oxidative Stress during Chronic Lead Intoxication. J Bioanal Biomed 5: 001-005. doi:10.4172/1948-593X.1000073

Copyright: @ 2013 Edrees G, et al. This is an open-access article distributed under the terms of the Creative Commons Attribution License, which permits unrestricted use, distribution, and reproduction in any medium, provided the original author and source are credited. 
Citation: Edrees G, Amer M, El-shamy K, Atta N (2013) Mammalian Neuro Endocrinological Changes and Oxidative Stress during Chronic Lead Intoxication. J Bioanal Biomed 5: 001-005. doi:10.4172/1948-593X.1000073

selected for the study. They have the same level of social life; and were non smokers or getting any drugs. A total of 30 male volunteers were studied. They included, control subjects $(\mathrm{n}=15)$, who lived away from any source of pollution as possible and Lead exposed subjects $(n=15)$. They were exposed to lead through their work as traffic soldiers for example or near bus station, battery factories. They are working in their field through the past 3 years at least. Blood samples were collected from each of them at $1 \mathrm{pm} \pm 30 \mathrm{~min}$. The study was approved according to scientific research ethics. Written informed consents were obtained from volunteers prior to the blood samples collection.

Blood samples were collected in clean tubes for hormonal and biochemical analysis, as was described for tested animals.

\section{Biochemical analysis}

Complete blood pictures were evaluated according to the method described at Dacie and Lewis [10]. MDA level was estimated according to the method of Ohkawa et al. [11]. GSH content was estimated by the method of Beutler et al. [12]. SOD activity was determined by the method of Nishikimi et al. [13].

Plasma $\mathrm{T}_{3}$ and $\mathrm{T}_{4}$ concentrations were estimated according described at Hollander and Shenkman [14]. Cortisol and testosterone concentrations were estimated according to Farmer and Pierce [15], and Ismail et al. [16], respectively.

Packed RBCs lead and plasma iron and zinc concentrations were determined by Atomic Absorption Spectrophotometer with air acetylene according to Zettner and Seligson [17]. Monoamines neurotransmitters content were determined by high performance liquid chromatography (HPLC) apparatus according to the method of Pagel et al. [18].

\section{Statistical analysis}

Data were analyzed using SPSS program (Statistical package for Social Science, version 17). For comparison of different mice groups, one way analysis of variance (ANOVA) was used followed by Tukey

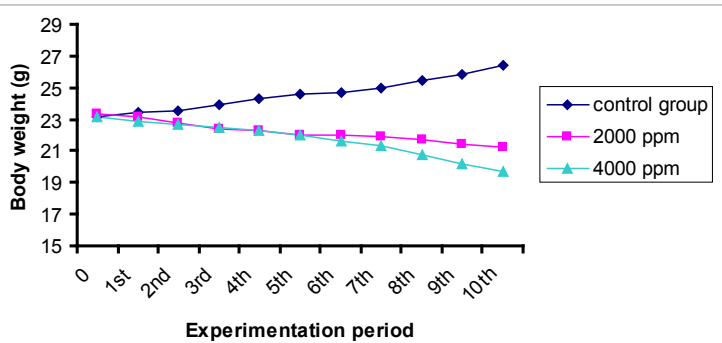

Figure 1: Mean body weight change in control and different lead intoxicated mice groups.

test, while comparison of the two human groups was carried out using independent Sample-t-test. The results were expressed as means \pm SD and values of $\mathrm{P} \leq 0.05$ were considered statistically significant.

\section{Results}

As showed in (Figure 1), there was a decrease in the body weight gain in lead intoxicated mice groups compared with control group.

Additionally, in table 1, there was a significant decrease in hemoglobin content, hematocrit percent, and RBCs in both lead treated mice groups and lead exposed human subjects compared to control ones. A significance decrease in WBCs count was also observed in the two dose (2000 and $4000 \mathrm{ppm}$ ) mice groups compared to control animals, however, there was no significant change in WBCs count in lead exposed human compared to control one.

Results presented in table 2 revealed significant decrease in GSH content in lead exposed human and high dose mice groups compared to normal ones, but there was significant increase in GSH content in mice treated by low dose lead compared to control group. SOD activity showed non-significant decrease in lead exposed human subjects, and significantly decrease in mice treated by high dose compared to control group. Also, there was a significant increase in MDA concentration in lead exposed human subjects and in both lead treated mice groups, compared to control group.

\begin{tabular}{|c|c|c|c|c|c|}
\hline \multirow{2}{*}{ Parameter Group } & \multicolumn{2}{|c|}{ Human subjects } & \multicolumn{3}{|c|}{ Experimental animals } \\
\hline & Normal & Lead exposed & Control & $\begin{array}{l}\text { Low dose exposure } \\
(2000 \mathrm{ppm})\end{array}$ & $\begin{array}{l}\text { High dose exposure } \\
(4000 \mathrm{ppm})\end{array}$ \\
\hline $\mathrm{Hb}(\mathrm{g} / \mathrm{dl})$ & $16.42 \pm 1.84$ & $10.04^{\mathrm{a}} \pm 1.56$ & $14.36 \pm 0.63$ & $11.83^{\mathrm{a}} \pm 1.07$ & $8.76^{a, b} \pm 0.65$ \\
\hline $\mathrm{Ht} \%$ & $45.54 \pm 3.37$ & $41.68^{\mathrm{a}} \pm 2.94$ & $40.03 \pm 3.2$ & $38.31 \pm 2.5$ & $26.35^{\mathrm{a}, \mathrm{b}} \pm 2.4$ \\
\hline RBCs $\left(\times 10^{6} / \mathrm{mm}^{3}\right)$ & $6.20 \pm 0.87$ & $4.78^{\mathrm{a}} \pm 0.51$ & $8.47 \pm 0.49$ & $7.66^{\mathrm{a}} \pm 0.68$ & $6.04^{a, b} \pm 0.47$ \\
\hline WBCs $\left(\times 10^{3} / \mathrm{mm}^{3}\right)$ & $7.77 \pm 1.74$ & $7.49 \pm 2.55$ & $1.97 \pm 0.64$ & $4.98^{a} \pm 0.85$ & $7.85^{a, b} \pm 0.64$ \\
\hline
\end{tabular}

Results are presented as means \pm SD ( $n=8$ for each mice group and 15 for human group) $a=S i g n i f i c a n t$ difference $(P<0.05)$ comparing to the normal control group (mice or human) $b=$ Significant difference $(P<0.05)$ comparing to $2000 \mathrm{ppm}$ lead acetate (low dose) group

Table 1: Hemoglobin content, hematocrit percent, erythrocytes and leucocytes count in control and different lead exposed mice and human.

\begin{tabular}{|c|c|c|c|c|c|c|}
\hline \multirow{2}{*}{ Parameter Group } & \multicolumn{2}{|c|}{ Human subjects } & \multirow[b]{2}{*}{ Parameter } & \multicolumn{3}{|c|}{ Experimental animals } \\
\hline & Control & Lead exposed & & Control & $\begin{array}{l}\text { Low dose exposure } \\
(2000 \mathrm{ppm})\end{array}$ & $\begin{array}{l}\text { High dose exposure } \\
(4000 \mathrm{ppm})\end{array}$ \\
\hline MDA (nmol/dl) & $18.73 \pm 7.4$ & $39.68^{a} \pm 2.84$ & MDA (nmol/g) & $4.30 \pm 2.18$ & $9.52^{\mathrm{a}} \pm 2.26$ & $24.16^{\mathrm{a}, \mathrm{b}} \pm 4.13$ \\
\hline GSH (mg/dl) & $34.5 \pm 7$ & $12.6^{\mathrm{a}} \pm 4.75$ & GSH (mg/g) & $12.97 \pm 0.87$ & $24.57^{\mathrm{a}} \pm 6.74$ & $10.94^{b} \pm 2.77$ \\
\hline SOD (U/dl) & $5.46 \pm 0.43$ & $4.16 \pm 0.22$ & $\operatorname{SOD}(\mathrm{U} / \mathrm{g})$ & $34.5 \pm 1.6$ & $28.5 \pm 1.6$ & $21.4^{\mathrm{a}, \mathrm{b}} \pm 2.1$ \\
\hline
\end{tabular}

Results are presented as means \pm SD ( $n=8$ for each mice group and 15 for human group) $\mathrm{a}=$ Significant difference $(\mathrm{P}<0.05)$ comparing to the normal control group (mice or human) $\mathrm{b}=$ Significant difference $(\mathrm{P}<0.05)$ comparing to 2000 ppm lead acetate (low dose) group

Table 2: Oxidative stress biomarkers in human sera and mice brain of control and different lead exposed subject. 
Citation: Edrees G, Amer M, El-shamy K, Atta N (2013) Mammalian Neuro Endocrinological Changes and Oxidative Stress during Chronic Lead Intoxication. J Bioanal Biomed 5: 001-005. doi:10.4172/1948-593X.1000073

Table 3 recorded decrease in $\mathrm{T} 3$ and $\mathrm{T} 4$ concentrations in lead exposed human subjects, but there was an increase in lead treated mice groups compared to control group. Testosterone concentration in both lead exposed human subjects and lead treated mice groups showed significant decrease compared to normal human subjects and control mice group, however, cortisol concentration exhibited an increase in lead exposed human subjects, and a decrease in lead treated mice groups compared to control one.

Table 4 showed a significant decrease in plasma $\mathrm{Zn}$ and Fe levels with increasing in $\mathrm{Pb}$ concentrations in lead intoxicated animals and human subjects compared with normal one. We notice, a reduction in dopamine content, but an increase in serotonin content in all lead exposed groups (Table 5).

\section{Discussion}

Lead is considered the most ubiquitous toxic metal detectable in the environment and in all biological systems. In the present study, chronic lead exposure exhibited marked decrease in mice body weight gain especially high dose (Figure 1) compared to control group and this could be due to toxic effect of lead on cellular metabolism and growth rate of animals. A view which is in accordance with Gupta and Gill [19], and/or enhancing glucose synthesis by mobilization of fat [20].

The present study revealed that lead exposure caused a significant decreased RBCs count; and $\mathrm{Hb}$ content these results agreed with Rice-
Evans [21], these result which may be due to a high affinity of lead for sulph-hydryl groups, particularly those of metallo-enzymes that impairs the biosynthesis of hemoglobin by interfering with several enzymatic steps in the heme pathway [22]. The decrease in RBCs count may also be due to lysis of RBCs by acute and high level lead absorption and/or inhibition of haem synthesis as well as decreasing red blood cell survival Levin and Goldberg [23]. Besides, prolonged lead exposure has been demonstrated to induce leucopenia, presented by decrease in WBCs count which may result from oxidative damage to the leucocytes [24].

Results in this study recorded a significant increase in MDA level after $\mathrm{Pb}$ exposure, which may be due to altered lipid composition of membranes due to lead exposure resulting in altered membrane integrity, permeability, and functions, so increases susceptibility to lipid peroxidation, a view which agreed with, Ahmed and Siddiqui [25]. A decrease in the level of antioxidants was also observed in both mice brain and in human blood. These results may be due to increased rate of lipid peroxidation and altered calcium and sulphydryl homeostasis. This decrease may also be attributed to enhanced level of ROS followed by oxidative stress, a view which agreed with, Abdel- Moneim et al. [26].

The observed decrease in SOD activity in $\mathrm{Pb}$ exposed groups may be due to the formation of superoxide radical, which possibly depleted the enzyme; this explanation is in agreement with, Cassini et al. [27]. In

\begin{tabular}{|c|c|c|c|c|c|}
\hline \multirow[b]{2}{*}{ Parameter } & \multicolumn{2}{|c|}{ Human subjects } & \multicolumn{3}{|c|}{ Experimental animals } \\
\hline & Control & Lead exposed & Control & $\begin{array}{l}\text { Low dose exposure } \\
(2000 \mathrm{ppm})\end{array}$ & $\begin{array}{l}\text { High dose exposure } \\
\text { (4000 ppm) }\end{array}$ \\
\hline T3 (ng/dl) & $118.53 \pm 23.54$ & $116.64 \pm 22.02$ & $4.61 \pm 1.06$ & $5.96 \pm 0.94$ & $8.47^{\mathrm{a}, \mathrm{b}} \pm 1.22$ \\
\hline $\mathrm{T} 4$ ( $\mu \mathrm{g} / \mathrm{dl})$ & $8.29 \pm 1.59$ & $7.42 \pm 1.71$ & $49.38 \pm 5.5$ & $62.57 \pm 9.01$ & $94.47^{\mathrm{a}, \mathrm{b}} \pm 15.87$ \\
\hline Testosterone (ng/ml) & $3.98 \pm 1.38$ & $1.64^{\mathrm{a}} \pm 0.65$ & $11.5 \pm 0.73$ & $9.05^{\mathrm{a}} \pm 1.46$ & $6.87^{\mathrm{a}, \mathrm{b}} \pm 0.48$ \\
\hline Cortisol ( $\mu \mathrm{g} / \mathrm{dl})$ & $6.07 \pm 2.51$ & $10.69^{a} \pm 1.96$ & $2.16 \pm 0.49$ & $1.2^{\mathrm{a}} \pm 0.26$ & $0.70^{\mathrm{a}, \mathrm{b}} \pm 0.52$ \\
\hline
\end{tabular}

Results are presented as means \pm SD ( $n=8$ for each mice group and 15 for human group) $a=$ Significant difference $(P<0.05)$ comparing to the normal control group (mice or human) $b=$ Significant difference $(P<0.05)$ comparing to 2000 ppm lead acetate (low dose) group

Table 3: Plasma Triiodothyronine (T3), Thyroxine (T4), Testosterone, and Cortisol hormones concentration in control and different lead exposed human and mice.

\begin{tabular}{|c|c|c|c|c|c|}
\hline \multirow{2}{*}{ Parameter Group } & \multicolumn{2}{|c|}{ Human subjects } & \multicolumn{3}{|c|}{ Experimental animals } \\
\hline & Control & Lead exposed & Control & $\begin{array}{l}\text { Low dose exposure } \\
(2000 \mathrm{ppm})\end{array}$ & $\begin{array}{l}\text { High dose exposure } \\
(4000 \mathrm{ppm})\end{array}$ \\
\hline $\mathrm{Pb}(\mu \mathrm{g} / \mathrm{g} \mathrm{Hb})$ & $9.83 \pm 1.06$ & $68.94^{\mathrm{a}} \pm 10.95$ & $14.5 \pm 2.6$ & $23.16^{a} \pm 2$ & $47.6^{\mathrm{a}, \mathrm{b}} \pm 6.5$ \\
\hline $\mathrm{Zn}(\mu \mathrm{g} / \mathrm{dl})$ & $210.1 \pm 19.15$ & $88.19^{a} \pm 18.3$ & $768 \pm 88.3$ & $333^{\mathrm{a}} \pm 103.8$ & $133^{\mathrm{a}, \mathrm{b}} \pm 16.9$ \\
\hline $\mathrm{Fe}(\mu \mathrm{g} / \mathrm{dl})$ & $63.12 \pm 6.7$ & $31.60^{a} \pm 12.1$ & $78.7 \pm 3.5$ & $48.5^{\mathrm{a}} \pm 4.4$ & $20.8^{\mathrm{a}, \mathrm{b}} \pm 7.3$ \\
\hline
\end{tabular}

Results are presented as means \pm SD ( $n=8$ for each mice group and 15 for human group) $a=S i g n i f i c a n t$ difference $(P<0.05)$ comparing to the normal control group (mice or human) $\mathrm{b}=$ Significant difference $(\mathrm{P}<0.05)$ comparing to2000 ppm lead acetate (low dose) group

Table 4: Lead RBCs concentration and plasma, $\mathrm{Zn}$ and Fe in control and different lead exposed human subjects and mice.

\begin{tabular}{|c|c|c|c|c|c|c|}
\hline \multirow[t]{2}{*}{ Group } & \multicolumn{2}{|c|}{ Human subjects } & \multirow{2}{*}{ Parameter Group } & \multicolumn{3}{|c|}{ Experimental animals } \\
\hline & Control & Lead exposed & & Control & $\begin{array}{c}\text { Low dose exposure } \\
(2000 \mathrm{ppm})\end{array}$ & $\begin{array}{l}\text { High dose exposure } \\
(4000 \mathrm{ppm})\end{array}$ \\
\hline Serotonin ( $\mu \mathrm{g} / \mathrm{dl})$ & $0.92 \pm 0.05$ & $1.03 \pm 0.07$ & Serotonin $(\mu \mathrm{g} / \mathrm{g})$ & $0.83 \pm 0.1$ & $1.09^{\mathrm{a}} \pm 0.08$ & $1.24^{\mathrm{a}, \mathrm{b}} \pm 0.06$ \\
\hline Dopamine ( $\mu \mathrm{g} / \mathrm{dl})$ & $0.47 \pm 0.04$ & $0.25 \pm 0.03$ & Dopamine $(\mu \mathrm{g} / \mathrm{g})$ & $1.45 \pm 0.07$ & $0.78^{a} \pm 0.04$ & $0.64^{\mathrm{a}, \mathrm{b}} \pm 0.05$ \\
\hline
\end{tabular}

Results are presented as means \pm SD ( $n=8$ for each mice group and 15 for human group)

$\mathrm{a}=$ Significant difference $(\mathrm{P}<0.05)$ comparing to the normal control group (mice or human)

$\mathrm{b}=$ Significant difference $(\mathrm{P}<0.05)$ comparing to $2000 \mathrm{ppm}$ lead acetate (low dose) group

Table 5: Monoamines content in mice brains $(\mu \mathrm{g} / \mathrm{g})$ and human serum $(\mu \mathrm{g} / \mathrm{dl})$ in control and different lead exposed animals and human subjects. 
addition, it seems that lead depletes cell thiol-containing antioxidants (GSH) or enzymes [28]. The neurotoxic effect of $\mathrm{Pb}$ may be attributed to the disturbance of pro-and antioxidative balance as reported by Bokara et al. [29]. $\mathrm{Pb}$ may also deteriorated cellular function decresing antioxidant via increased production of $\mathrm{ROS}, \mathrm{H}_{2} \mathrm{O}_{2}$ and $\mathrm{NO}$ [30]. However, obtained increase in GSH content in low dose lead exposed mice, may be due to a protective or compensatory mechanism, wherein, lead might bind with GSH in order to reduce the toxicity Hsu [31].

Obtained decrease in serum T3 and T4 in the present study after $\mathrm{Pb}$ exposure, may be due to the fact that lead inhibits synthesis and release of thyroid hormone at the glandular level through affecting thyroid iodine uptake or TSH release from pituitary or TRH release from hypothalamus [32] and/or the role of $\mathrm{Pb}$ in damage thyroid gland [33]. In addition to the suppresses role of $\mathrm{Pb}$ for synthesis and release of thyroid hume at the glandular level [34]. On the other hand, the increased serum T3 and T4 in lead exposed animals may be due to altering TSH values and presumably thyroid hormones [35]. The increased serum cortisol observed in lead exposed subjects was in concern with results of Fengyuan et al. [34], and may be due to respond to oxidative stress caused by lead exposure [36].

The recorded decrease in testosterone concentrations in $\mathrm{Pb}$ exposed individuals, may be due to direct toxic action of lead on the testes with reducing production of testosterone, or decreasing testicular sensitivity to gonadotrophic actions [37]. The anti- androgenic activity of $\mathrm{Pb}$ may also lead to this result [38].

Results of the present study indicated that lead was capable of causing decrease in plasma iron concentration, this result may be due to competition between lead and iron resulting in decreased blood total iron under low or high dose of lead exposure [39]. Obtained decrease plasma zinc in $\mathrm{Pb}$ exposed subject may be due to the inhibition of ferrochelatase enzyme which exceeds formation of zinc protoporphyrin that excreted with urine and leads to decrease in zinc and iron concentration [40].

The decreased levels of dopamine observed following lead exposure could be the result of altered activity of biosynthetic and degradive enzymes, or altered availability of their precursor amino acid tyrosin [19]. However, the resulted increase in serotonin level may be attributed to activation of tryptophan hydroxylase.

The neurodegenerative disorders caused by $\mathrm{Pb}$ may lead to these neurotransmitters abnormalities [41]. The interference of $\mathrm{Pb}$ with dopaminergic transmission at the presynaptic level may caused this alternation [42]. The neurotransmitter production may affect interference of $\mathrm{Pb}$ with normal neural cell adhesion [43].

In conclusion, lead disturbs the delicate balance of micronutrients, such as $\mathrm{Zn}$ and Fe, which is important in the physiology of neuronal functions, these, in turn, can cause alterations of neurotransmitters such as dopamine, and serotonin, as well as affecting several indicators of oxidative stress. A disturbance in hormonal balance was also demonstrated in both mice and human individual after lead intoxication. Thus, it seems that the potential health hazards of lead poisoning still exist, and this due to lack of education regarding the precautions of workers with lead, and how to avoid $\mathrm{Pb}$ pollutant area.

\section{References}

1. Solliway BM, Schaffer A, Pratt H, Yannai S (1996) Effects of exposure to lead on selected biochemical and haematological variables. Pharmacol Toxicol 78: 18-22.
2. Silbergeld EK (2000) Lead as a carcinogen: Experimental evidence and mechanisms of action. Am J Indust Med 38: 316-323.

3. Nevin R (2007) Understanding international crime trends: the legacy of preschool lead exposure. Environ Res 104: 315-336.

4. Gurer-Orhan H, Sabir HU, Ozgune SH (2004) Correlation between clinica indicators of lead poisoning and oxidative stress parameters in controls and lead-exposed workers. Toxicology 195: 147-154.

5. White LD, Cory-Slechta DA, Gilbert ME, Tiffany-Castiglioni E, Zawia NH (2007) New and evolving concepts in the neurotoxicology of lead. Toxicol Appl Pharmacol 225: 1-27.

6. Toscano CD, Guilarte TR (2005) Lead neurotoxicity: from exposure to molecular effects. Brain Res Brain Res Rev 49: 529-554.

7. Soltaninejad K, Kebriaeezadeh A, Minaiee B, Ostad SN, Hosseini, et al. (2003) Biochemical and ultrastructural evidences for toxicity of lead through free radicals in rat brain. Hum Exp Toxicol 22: 417-423.

8. Villeda-Hernandez J, Barroso-Moguel R, Mendez-Armenta M, Nava-Ruiz C Huerta R, et al. (2001) Enhanced brain regional lipid peroxidation in developing rats exposed to low level lead acetate. Brain Res Bull 55: 247-251.

9. Coery-Slechta DA (1995) Relationships between lead-induced learning impairments and changes in dopaminergic, cholinergic and glutamatergic neurotransmitter system functions. Annu Rev Pharmacol Toxicol 35: 391-415.

10. Dacie JV, Lewis SM (1991) Practical Haematology. "Basic Haematological Technique Estimation of Red Cell". (7thedn), 41-47.

11. Ohkawa H, Ohishi N, Yagi K (1982) Assay for lipid peroxides in animal tissues by thiobarbituric acid reaction. Anal Biochem 95: 351-358.

12. Beutler E, Duron O, Kelly MB (1963) Improved method for the determination of blood glutathione. J Lab Clin Med 61: 882-888.

13. Nishikimi M, Roa NA, Yagi K (1972) The occurrence of superoxide anion in the reaction of reduced phenazine methosulphate and molecular oxygen. Biochem Biophys Res Commun 46: 849-854.

14. Hollander CS, Shenkman L (1974) Radioimmunoassay for triiodothyronine and throxine. In: Rothfeld, B. editor. Nuclear medicine in vitro. Philadelphia: Lippincott, pp. 136-149.

15. Farmer RW, Pierce CE (1974) Plasma cortisol determination: radioimmunoassay and competitive protein binding compared. Clin Chem 20: 411-414.

16. Ismail A, Astley P, Burr WA, Cawood M, Short F, et al. (1986) The role of testosterone measurement in the investigation of androgen disorders. Ann Clin Biochem 23: 113-134.

17. Zettner A, Seligson D (1963) Quited from Hawk's Physiological Chemistry (14thedn), Published by Tata Mc-Graw-Hill Publishing Company LTD. New Delhi, 1008-1136.

18. Pagel P, Blome J, Wolf HU (2000) High-performance liquid chromatographic separation and measurement of various biogenic compounds possibly involved in the pathomechanism of Parkinson's disease. J Chromatgr B Biomed Sc Appl 746: 297-304

19. Gupta V, Gill KD (2000) Lead and ethanol coexposure: Implications on the dopaminergic system and associated behavioral functions. Pharmacol Biochem Behav 66: 465-474.

20. Tendon SK, Tewari PC (1987) Effect of coexposure to ethanol and cadmium in rats. Bull Environ Contam Toxicol 39: 633-640.

21. Rice-Evans C (1990) Iron-mediated oxidative stress and erythrocytes. In: Harris JR (ed.), Blood Cell Biochemistry. Plenum Press New York 11: 429-453.

22. ASTDR (2007) Toxicological Profile for Lead United States Public Health Service. Atlanta, GA: Agency for Toxic Substances and Disease Registry.

23. Levin SD, Goldberg M (2000) Clinical evaluation and management of leadexposed construction workers. Am J Ind Med 37: 23-43.

24. Ambali FS, Angani M, Shittu M, Kawu UM (2011) Hematological changes induced by subchronic co-administration of chlorpyrifos and lead in Wistar rats: Alleviating effect of vitamin C. Der Pharmacia Sinica 2: 276-284.

25. Ahmed M, Siddiqui MK (2007) Low level lead exposure and oxidative stress: Current opinions. Clinica Chimica Acta 383: 57-64. 
Citation: Edrees G, Amer M, El-shamy K, Atta N (2013) Mammalian Neuro Endocrinological Changes and Oxidative Stress during Chronic Lead Intoxication. J Bioanal Biomed 5: 001-005. doi:10.4172/1948-593X.1000073

26. Abdel-Moneim AE, Dkhil MA, Al-Quraishy S (2011) Effects of flaxseed oil on lead acetate-induced neurotoxicity in rats. Biol Trace Elem Res 144: 904-913.

27. Cassini C, Calloni C, Bortolini G, Garcia SC, Dornelles MA, et al. (2011) Occupational risk assessment of oxidative stress and genotoxicity in workers exposed to paints during a working week. Int J Occup Med Environ Health 24: 308-319.

28. Ercal N, Gurer-Orhan H, Aykin-Burns N (2001) Toxic metals and oxidative stress part I: mechanisms involved in metal-induced oxidative damage. Curr Top Med Chem 1: 529-539.

29. Bokara KK, Brown E, McCormick R, Yallapragada PR, Rajanna S, et al. (2008) Lead-induced increase in antioxidant enzymes and lipid peroxidation products in developing rat brain. Biometals 21: 9-16.

30. Hamed OA, Eman HM, El-Karraksy AO, Mostaffa T, Gad Allah A (2001) Impotence, lead and oxidative stress: Do they form a serious triangle? I-A comparative toxicological biochemical study of cavernous tissue versus peripheral blood. Mansoura J Forensic Med Clin Toxicol 9: 25-46.

31. Hsu JM (1981) Lead toxicity as related to glutathione metabolism. J Nutr 111 26-33.

32. Robins JM, Cullen MR, Connors BB, Kayne RD (1983) Depressed thyroid indexes associated with occupational exposure to inorganic lead. Arch Intern Med 143: 220-242.

33. Dundar B, Oktem F, Arslan MK, Delibas N, Baykal B, et al. (2006) The effect of long-term low-dose lead exposure on thyroid function in adolescents. Environ Res 101: 140-145.

34. Fengyuan P, Cheng F, Chen H, Li G, Liu S, et al. (2007) Effect of Zinc Coadministration on Lead Toxicities in Rats. Ind Health 45: 546-551.
35. Lopez CM, Pineiro AE, Nunez N, Avagnina AM, Villaamil EC, et al. (2000) Thyroid hormone changes in males exposed to lead in the Buenos aires area (Argentina). Pharmacol Res 42: 599-602.

36. Flora SJ, Saxena G, Mehta A (2007) Reversal of lead-induced neuronal apoptosis by chelation treatment in rats: role of reactive oxygen species and intracellular $\mathrm{Ca}\left(2^{+}\right)$. J Pharmacol Exp Ther 322: 108-116.

37. Ng TP, Goh HH, Ng YL, Ong HY, Ong CN, et al. (1991) Male endocrine functions in workers with moderate exposure to lead. $\mathrm{Br} \mathrm{J}$ Ind Med 48: 485-491.

38. Okamura K, Kizu R, Toriba A, Klinge CM, Hayakawa K (2002) Antiestrogenic activity of extracts of diesel exhaust particulate matter in MCF-7 human breast carcinoma cells. Polycycl Aromat Compd 22: 747-759.

39. Hamadouche AIT N, Slimani M, Aous AEK (2009) Biochemical parameters alterations induced by chronic oral administration of lead acetate in albino rats. Am J Sci Res 4: 5-16.

40. Jin C, Li Y, Li YL, Zou Y, Zhanga GL, et al. (2008) Blood Lead: Its effect on trace element levels and iron structure in hemoglobin. Nucl Instrum Methods Phys Res B 266: 3607-3613.

41. Kregel KC, Zhang HJ (2007) An integrated view of oxidative stress in aging basic mechanisms, functional effects, and pathological considerations. Am J Physiol Regul Integr Comp Physiol 292: 18-36.

42. Missale C, Battaini F, Govoni S, Castelletti L, Spano PF, et al. (1984) Chronic lead exposure differentially affects dopamine transport in rat striatum and nucleus accumbens. Toxicology 33: 81-90.

43. Dietrich KN (1999) Environmental chemicals and child development. J Pediat 134: 7-9. 